\title{
Sprawozdanie z prac w Studium Polski Podziemnej w Londynie w 2018 r.
}

W dniach 18 czerwca - 18 lipca 2018 r. przebywałyśmy w Studium Polski Podziemnej w Londynie, wykonując prace $\mathrm{w}$ ramach programu wspierania instytucji polonijnych realizowanego przez Naczelną Dyrekcję Archiwów Państwowych.

Podczas tegorocznego pobytu kontynuowałyśmy działania rozpoczęte w 2017 r. ${ }^{1}$, mające na celu przygotowanie do digitalizacji zespołu KW 1 - Akta Komisji Weryfikacyjnej. Obejmowały one nadawanie jednolitego układu wewnątrz teczek (według kryteriów przyjętych w 2017 r.), korygowanie błędów w układzie alfabetycznym, ewidencjonowanie akt w arkuszu kalkulacyjnym MS Excell, nadawanie nowych sygnatur, usuwanie elementów metalowych, paginowanie.

Akta Komisji Weryfikacyjnej KW 1 powstały w wyniku działalności Głównej Komisji Weryfikacyjnej AK w latach 1945-1949², która sprawdzała przynależność osób do Armii Krajowej lub innych formacji zbrojnych i potwierdzała udział w działaniach wojennych lub dywersyjnych. Przed podjęciem prac akta nie posiadały żadnych pomocy archiwalnych, zostały jedynie podzielone przez aktotwórcę na teczki osobowe, którym nadano układ alfabetyczny.

Zawartość teczek osobowych jest w dużej mierze jednolita - obejmują one przede wszystkim dokumenty przedstawiane przez osoby poddające się weryfikacji, tj. kwestionariusze osobowe, życiorysy, relacje nt. losów w czasie wojny, oświadczenia świadków o pełnionej służbie, zaświadczenia z przebiegu służby, w niektórych wypadkach również inne materiały potwierdzające służbę wojskową, np. legitymacje i fotografie oraz pisma komisji weryfikacyjnej odzwierciedlające proces weryfikacji, tj. korespondencję i zaświadczenia weryfikacyjne.

W trakcie miesięcznego pobytu zewidencjonowałyśmy i technicznie przygotowałyśmy do digitalizacji 1312 j.a. (liczących 2,2 mb i 19344 stron). Po zakończeniu naszego pobytu w Studium prace nad zespołem kontynuowali koledzy z Archiwum Państwowego w Szczecinie oraz pracownik Studium, co pozwoliło przystąpić do digitalizacji zespołu.

Akta Komisji Weryfikacyjnej KW 1 zawierają ciekawe materiały o charakterze biograficznym na temat wielu osób, które po wojnie znalazły się w Wielkiej Brytanii. Mogą one stanowić przyczynek do badań nad początkami polskiej emigracji w Wielkiej Brytanii oraz dotyczących losów powstańców warszawskich, członków AK i innych formacji oraz ludności cywilnej, których wydarzenia wojenne rzuciły poza granice kraju. $Z$ tego względu

${ }^{1}$ Anna Sokół, Aldona Warzecha, Sprawozdanie z prac w Studium Polski Podziemnej w Londynie w 2017 r., „Krakowski Rocznik Archiwalny” 2017, t. 23, s. 273-274.

2 Andrzej Suchcitz, Informator Studium Polski Podziemnej 1947-1997, Londyn 1997, s. 136. 
stanowią niezwykle wartościowy zespół archiwalny, który zasługuje na uwagę zarówno badaczy okresu II wojny światowej, jak i osób niezajmujących się badaniami historycznymi zawodowo.

Anna Sokót, Aldona Warzecha Archiwum Narodowe w Krakowie 